MINERALOGIA, 46, No 1-2: 3-18 (2015)

Original paper

\title{
Exceptional Tl-bearing manganese oxides from Zalas, Krakow area, southern Poland
}

\author{
Bożena Gołębiowska ${ }^{1^{*}}$, Grzegorz Rzepa ${ }^{1}$ and Adam Pieczka ${ }^{1}$ \\ ${ }^{I}$ AGH - University of Science and Technology, Faculty of Geology, Geophysics and Environmental Protection, \\ Al. A. Mickiewicza 30, 30-059 Kraków, Poland \\ goleb@agh.edu.pl \\ * Corresponding author
}

Received: September 9, 2015

Received in revised form: February 12, 2016

Accepted: March 15, 2016

Available online: April 15, 2016

\begin{abstract}
In the Permian rhyodacite quarry at Zalas near Krakow, southern Poland, thallium-bearing Mn oxides occur in a small fault zone cutting Middle Jurassic sandy limestone poorly encrusted by an oxidized polymetallic mineralization. The encrustation comprises sulphides (pyrite, chalcopyrite, chalcocite, covellite, galena, marcasite), native bismuth, hematite, goethite, cuprite, mottramite, iodargyrite, unrecognized $\mathrm{Cu}$ sulphates and $\mathrm{Bi}$ oxychlorides as supergene minerals, barite and rare tiny grains of gold. It is most likely connected with rejuvenation of Early-Paleozoic faults during the Alpine orogeny on the Oligocene-Miocene boundary. Rare Tlbearing $\mathrm{Mn}$ oxides occur in an outside zone of the encrustations, filling small fractures and voids in limestone forming the fault breccia. $\mathrm{Tl}$ contents, reaching $20.82 \mathrm{wt} \%$ as $\mathrm{Tl}_{2} \mathrm{O}$, exceed by more than two orders of magnitude those reported in similar minerals before, making the oxides unique on a world scale. The Tl-bearing Mn oxides from Zalas reflect intensive weathering of an older Tl-bearing sulphide mineralization in an arid climate, involving saline fluids delivered to the groundwater system as the nappe structure of the Carpathians was developing during the Sava tectonic phase Oligocene/Miocene boundary.
\end{abstract}

Key-words: thallium, Mn oxides, Cracow-Silesia Monocline, Zalas, oxidized polymetallic ores

\section{Introduction}

In-situ fossil, preglacial-oxidized, polymetallic mineralization at Zalas in the Krakow area, southern Poland, found in a breccia coming from a small fault zone exposed by mining works in 2005 . The mineralization is generally composed of relics of primary 
sulphides and their supergene products as well as Mn oxides, which, in some cases, contain significant $\mathrm{Ca}, \mathrm{Ba}, \mathrm{Pb}, \mathrm{Co}, \mathrm{Ni}$ and $\mathrm{Tl}$ contents (Gołębiowska et al. 2010). Although a link between weathering-stage $\mathrm{Mn}$ oxides and thallium is well known in $\mathrm{Tl}$ geochemistry (Critteden et al. 1962; Schmiermund 2008; Kabata-Pendias 2011), this discovery is of world significance due to unusually high $\mathrm{Tl}$ contents reaching $20.82 \mathrm{wt} \%$ as $\mathrm{Tl}_{2} \mathrm{O}$.

Thallium minerals are very rare in nature. Only about 50 species are known and none is a Mn oxide. Usually, they comprise sulphides, arseno- or antimono-sulphides, mainly related to the epithermal stage of hydrothermal activity. Only three oxidized $\mathrm{Tl}$ species are known: avicennite, $\mathrm{Tl}_{2} \mathrm{O}_{3}$ (Karpova et al. 1958), dorallcharite, $(\mathrm{Tl}, \mathrm{K}) \mathrm{Fe}^{3+}{ }_{3}\left(\mathrm{SO}_{4}\right)_{2}(\mathrm{OH})_{6}$ (Balić-Žunić et al. 1994) and lanmuchangite, $\mathrm{TlAl}\left(\mathrm{SO}_{4}\right)_{2} \cdot 12 \mathrm{H}_{2} \mathrm{O}$ (Daiyan et al. 2003). An aluminosilicate melt can be primary source of $\mathrm{Tl}$; in such, $\mathrm{Tl}^{+}$, along with $\mathrm{Rb}^{+}$, can substitute for $\mathrm{K}^{+}$in rock-forming minerals, e.g., plagioclase can contain $<100 \mathrm{ppm} \mathrm{Tl}$, K-feldspars $<610 \mathrm{ppm}$ and micas $<380 \mathrm{ppm}$ (Jović 1993). Thallium contents in common late sulphides such as galena and sphalerite can exceed 5000 and $1000 \mathrm{ppm}$, respectively (Wedepohl 1978) due to the concentration of the element by low-temperature hydrothermal and metasomatic processes. Contents up to $5 \mathrm{wt} \% \mathrm{Tl}$ have been noted in chalcopyrite (John Peter, Viraraghavan 2005) and up to $3.5 \mathrm{wt} \%$ in pyrite (Zhou et al. 2005; Schmiermund 2008). During weathering, $\mathrm{Tl}$ is mobilized and easily transported along with alkaline metals (Lin, Nriagu 1999), and fixed by Mn oxides, clays and organic matter (Kabata-Pendias 2011; Voegelin et al. 2015).

In this paper, the compositions of the Tl-bearing Mn oxides from the oxidation zone at Zalas are discussed in order to evaluate the reasons for such atypically-high $\mathrm{Tl}$ concentrations in some of the oxides.

\section{Geological setting}

Zalas is located about $20 \mathrm{~km}$ west of Krakow and about $5 \mathrm{~km}$ south of Krzeszowice in the southern marginal part of the Cracow-Silesia Monocline (CSM), formed during the Laramide orogeny from Mesozoic deposits (Fig. 1). This part of the CSM is arranged in a system of horsts and grabens resulting from the northward overthrusting of Carpathian flysch nappes in the Paleogene during the Alpine orogeny. The basement of the monocline includes strata from Precambrian (Ediacaran) to Carboniferous with numerous sequences of Upper Carboniferous and Permian volcanic rocks that are occasionally exposed at the surface (Buła 2002), as at Zalas.

At Zalas, a rhyodacite laccolith has been exploited for some decades. The laccolith was formed about 280-260 Ma during an Early Permian transtensional, sinistral tectonic regime with transtension propagated along the Krakow-Lubliniec fracture zone (Nawrocki et al. 2005), formed in the Early Paleozoic and active until the Cenozoic (Matyszkiewicz 1997; Żaba 1999; Buła 2002; Matyszkiewicz et al. 2006).

Quarrying operations periodically expose small faults and fissures cutting the Middle Jurassic limestone occurring as a capstone. The limestone locally contains abundant detrital material: quartz, more rarely K-feldspars and alkali plagioclases, clays, lamprophyre clasts, partly altered amphiboles and apatites, rutile, titanomagnetite, titanite, zircon, monazite(Ce) and xenotime-(Y). Breccia in the faults and fissures is poorly encrusted with Fe and $\mathrm{Mn}$ oxides and, occasionally, small relics of polymetallic mineralization. One of such 
zones, poorly encrusted with supergene $\mathrm{Cu}$ minerals, was exposed by a short time in 2005 . The mineralization contained small relics of sulphides (pyrite, chalcopyrite, chalcocite, covellite, galena and marcasite), native bismuth, barite, rare small grains of gold and supergene minerals: hematite, goethite, cuprite, mottramite, iodargyrite, unrecognized $\mathrm{Cu}$ sulphates and $\mathrm{Bi}$ oxychlorides. The mineralization has been related to rejuvenation in the Sava phase during the Alpine orogeny of Early-Paleozoic fault zones, cutting the oremineralized basement of the CSM, and intensive weathering under semi-arid and arid climate in a period between the Oligocene and Middle Miocene (Gołębiowska et al. 2010).



Fig. 1. Geological map of the Krakow area, without Quaternary (after Gradziński et al. 1994, simplified).

\section{Methods}

The chemical compositions of the Tl-bearing Mn oxides were analysed using a Jeol SuperProbe JXA-8230 in the Laboratory of Critical Elements AGH-KGHM at the AGH University of Science and Technology (Krakow, Poland), operating in wave-lengthdispersive mode under the following conditions: accelerating voltage of $15 \mathrm{kV}$, beam current of $20 \mathrm{nA}$, peak count-time of $20 \mathrm{~s}$ and background time of $10 \mathrm{~s}$. Standards, analytical lines, diffracting crystals and mean detection limits (in wt\%) were as follows: 


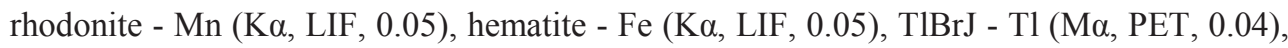

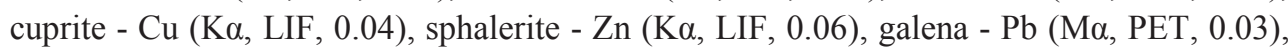

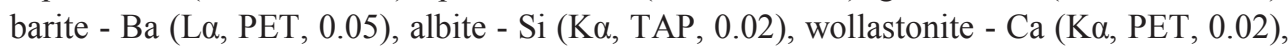

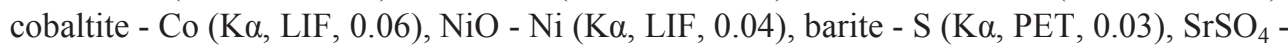

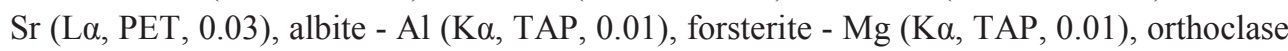
- K (K $\alpha$, PET, 0.01), albite - Na (K $\alpha$, TAP, 0.02).

Back-scattered electron (BSE) imaging of polished sections was obtained using a FEI Quanta 200 FEG scanning electron microscope, equipped with an EDS detector. The system operated at $25 \mathrm{kV}$ accelerating voltage in a high-vacuum mode.

Powder X-ray diffraction (XRD) patterns of Mn-oxides (excepting the Tl-rich variety due to its extremely small amount) were collected at room temperature with a Philips APD X'Pert PW2030 diffractometer, under the following conditions: graphite-monochromatized $\mathrm{Cu} K \alpha$ radiation with $\lambda=1.5418 \AA$, accelerating voltage of $35 \mathrm{kV}$, beam current of $30 \mathrm{~mA}$, registration velocity of $0.02^{\circ}(2 \Theta) / 1 \mathrm{~s}$, registration range of $2-75^{\circ}(2 \Theta)$. The data were analysed using $X$ 'rayan software (Marciniak et al. 2006) and X-ray standards in the form of ICDD files.

\section{Results}

Two representative fragments of the fault breccia hosted by the Callovian sandy limestone, encrusted with malachite and Fe and Mn oxides, are shown on Figure 2. These oxides, commonly occur in the form of tiny disseminated grains or cryptocrystalline aggregates that give a yellowish to red-brownish pigmentation of the encrusted zones, or rarely as massive or rosette aggregates (Fe oxides and Mn oxides, respectively) up to a few millimetres across. In close proximity to sulphide relics and malachite encrusted with iodargyrite, the oxides are mainly hematite and goethite, in some cases, as pseudomorphs after pyrite cubes and, more rarely, $\mathrm{Mn}$ oxides enriched in $\mathrm{Co}, \mathrm{Ni}, \mathrm{Pb}, \mathrm{Ca}$ and $\mathrm{Ba}$. The $\mathrm{Co}-$ and Ni-bearing oxides commonly form vein-like aggregates $>70 \mu \mathrm{m}$ in length and $>5 \mu \mathrm{m}$ in thickness or radial forms of similar sizes with a Pb-bearing variety in their outermost zones (Fig. 3A). These Mn oxides contain (Co- and Ni-bearing phases vs the Pb-bearing phase; all in wt \%): $\mathrm{CoO} 13.78-16.52 \mathrm{vs}<2.25$ at $\mathrm{NiO}$ contents of 4.34-9.51 vs $<0.62, \mathrm{CuO}$ in the range 7.42-10.66 vs 7.9-9.1, $\mathrm{PbO}<0.24$ vs 22.5-22.6, and traces of $\mathrm{CaO}(2.07-2.80$ vs $0.7-0.8), \mathrm{Fe}_{2} \mathrm{O}_{3}(0.9-4.7$ vs $\sim 1.0), \mathrm{Al}_{2} \mathrm{O}_{3}(2.06-5.67$ vs $0.4-0.5)$ and $\mathrm{SiO}_{2}(0.09-0.69$ vs $\sim 0.55$ ). In addition, the Co- and Ni-bearing $\mathrm{Mn}$ oxides contain traces of $\mathrm{ZnO}$ (up to 0.66), whereas the $\mathrm{Pb}$-bearing oxide contains $\mathrm{SrO}(\sim 0.05), \mathrm{BaO}$ (up to 1.54) and $\mathrm{Tl}_{2} \mathrm{O}$ (up to 0.53). The $\mathrm{Ba}$ - or Ca-bearing $\mathrm{Mn}$ oxides occur only in the outer zones of zoned $\mathrm{MnO}_{2}$ aggregates with almost pure $\mathrm{MnO}_{2}$ in their cores (Fig. 4). They contain (in wt\%) 78.1683.54 $\mathrm{MnO}_{2}, 3.39-10.55 \mathrm{BaO}, 2.49-4.56 \mathrm{CaO}$, up to $2.91 \mathrm{Fe}_{2} \mathrm{O}_{3}$, and $<1.0 \mathrm{wt} \%$ of $\mathrm{Al}_{2} \mathrm{O}_{3}$, $\mathrm{SiO}_{2}$ and $\mathrm{SrO}$, and are devoid of $\mathrm{CuO}$ and $\mathrm{Tl}_{2} \mathrm{O}$. All the oxides were identified by XRD as birnessite, ranciéite and todorokite (Gołębiowska et al. 2007). 



Fig. 2. Tiny voids and fissures in a Callovian sandy limestone at Zalas abundance filled with Mn and $\mathrm{Fe}$ oxides, malachite and calcite (photo $\mathrm{A}$ ) and $\mathrm{Fe}$ oxides, malachite and other subordinate supergene mineralization (photo B).
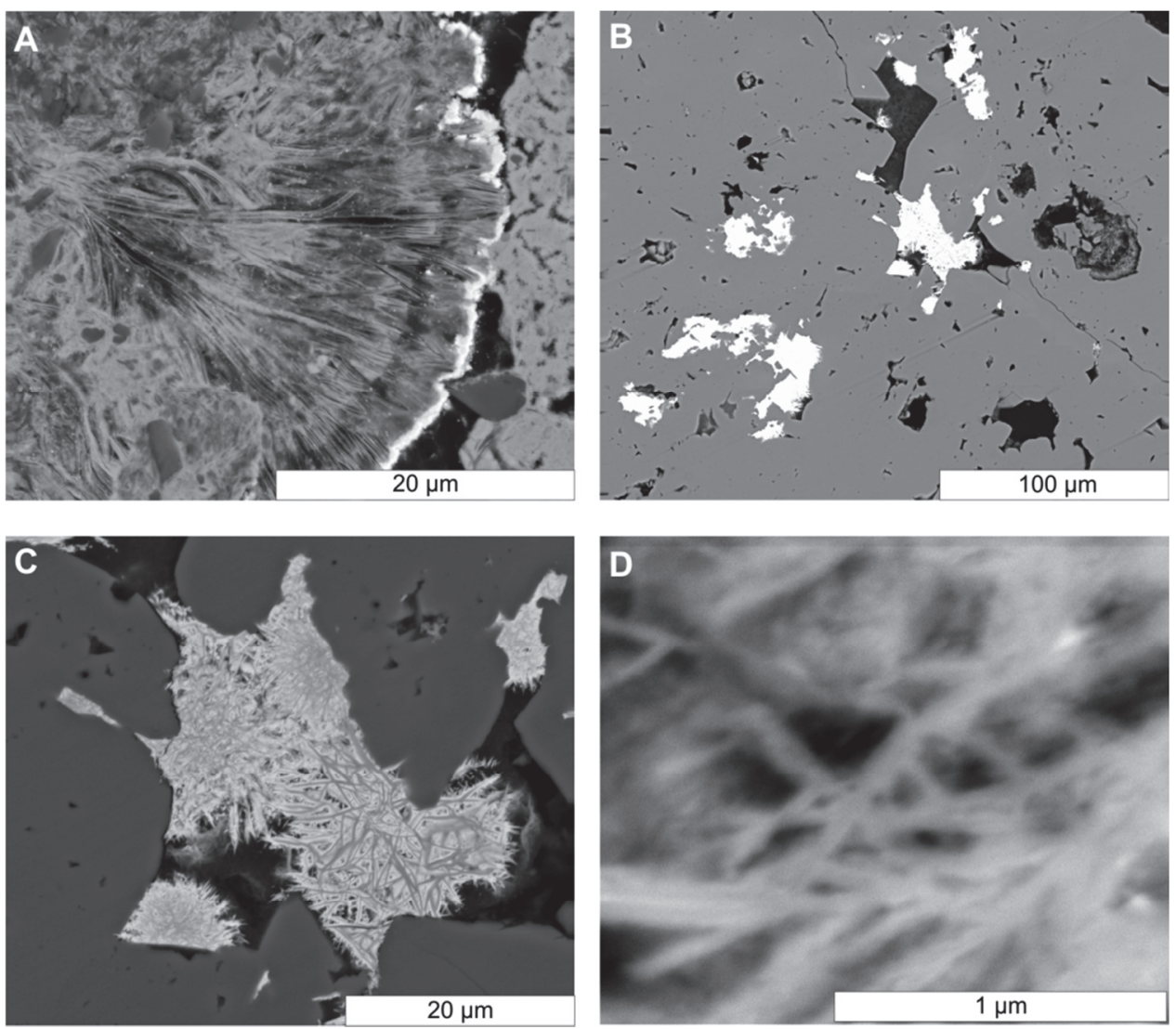

Fig. 3. BSE images of Mn oxides from Zalas. A - A spherulite comprising Co- and Ni-bearing Mn oxides with a Pb-dominant variety in the outermost zone (bright rim). B, C, D - Fibrous, highly porous, 'sugar wool' aggregates of Tl-bearing Mn oxides (the image on Figure $\mathrm{C}$ is enlarging the image on Figure B). 

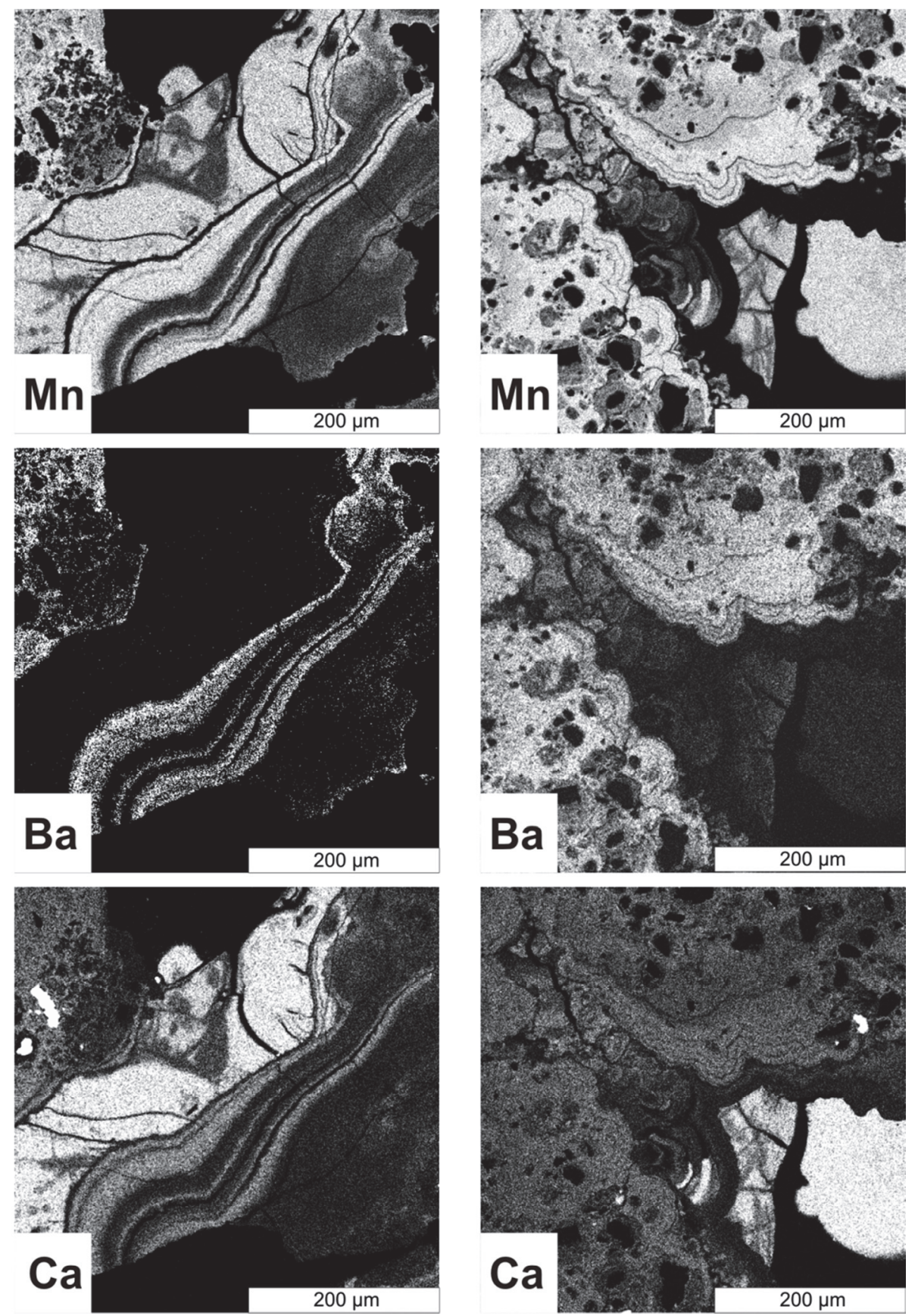

Fig. 4. Distribution of select elements in Ba- and Ca-bearing Mn-oxides from Zalas. Pay attention to Ca-Mn oxide (ranciéite) overgrown by regular zones of a Ba-Mn oxide. 
Thallium-bearing Mn oxides were found in only one fragment of the encrusted breccia. They generally occur outside the polymetallic encrustations, in the form of tiny aggregates $<50 \mu \mathrm{m}$ in size, filling small fractures and voids in the limestone. Their texture, usually fibrous, highly porous, xerogel-like reminiscent of sugar wool (cf. Bodeï et al. 2007) may suggest a phyllomanganate possible nano-sized birnessite (Fig. 3B-D). In spite of the nanosized texture of the oxide, the fact that its fibres seem to be homogeneous (Fig. 3D) suggests that it is not a mixture of avicennite, $\mathrm{Tl}_{2} \mathrm{O}$ with a $\mathrm{MnO}_{2}$ oxide. The $\mathrm{Tl}$ content of the oxides expressed as $\mathrm{Tl}_{2} \mathrm{O}$ ranges from 9.92 to $20.82 \mathrm{wt} \%(9.55-20.04 \mathrm{wt} \% \mathrm{Tl})$ at a rather constant $\mathrm{MnO}_{2}$ content (in wt \%) of 63.90-68.85, CuO: 4.83-7.68, BaO: 2.89-4.91, CoO: 0.28-1.27, NiO: $0.15-0.65$, low $\mathrm{CaO}: 1.09-2.70, \mathrm{Fe}_{2} \mathrm{O}_{3}$ up to $1.57, \mathrm{PbO}<$ up to $0.34, \mathrm{SiO}_{2}$ up to $0.57, \mathrm{~K}_{2} \mathrm{O}$ up to 0.19 , and negligible $\mathrm{SrO}, \mathrm{Na}_{2} \mathrm{O}, \mathrm{MgO}, \mathrm{Al}_{2} \mathrm{O}_{3}$ and $\mathrm{ZnO}$ (Table 1). A correlation between the contents of $\mathrm{Tl}$ and totals of other mono- and 2-valent elements in the Tl-bearing Mn oxides reveals their linear dependence with a very high correlation coefficient $\mathrm{R}^{2}=0.96$ (Fig. 5).

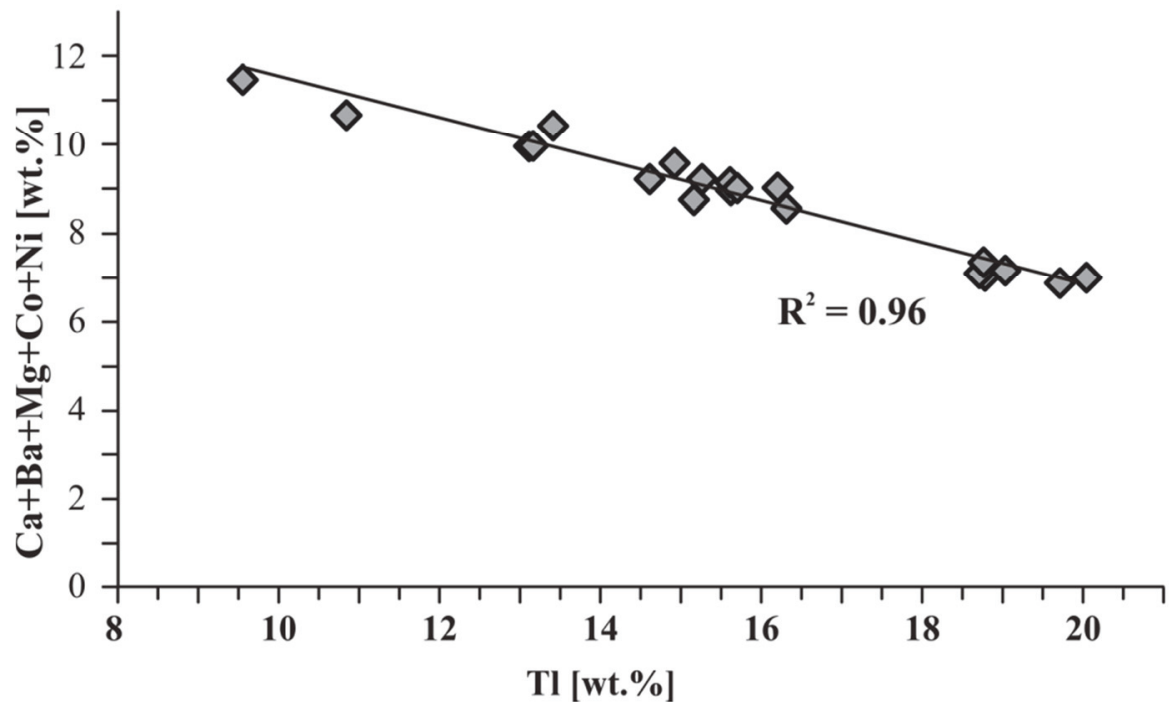

Fig. 5. Correlation between $\mathrm{Tl}$ and totals of 2 -valent elements $(\mathrm{Ca}+\mathrm{Ba}+\mathrm{Mg}+\mathrm{Co}+\mathrm{Ni})$ in the $\mathrm{Tl}$-bearing Mn oxides (in wt $\%$ ). 


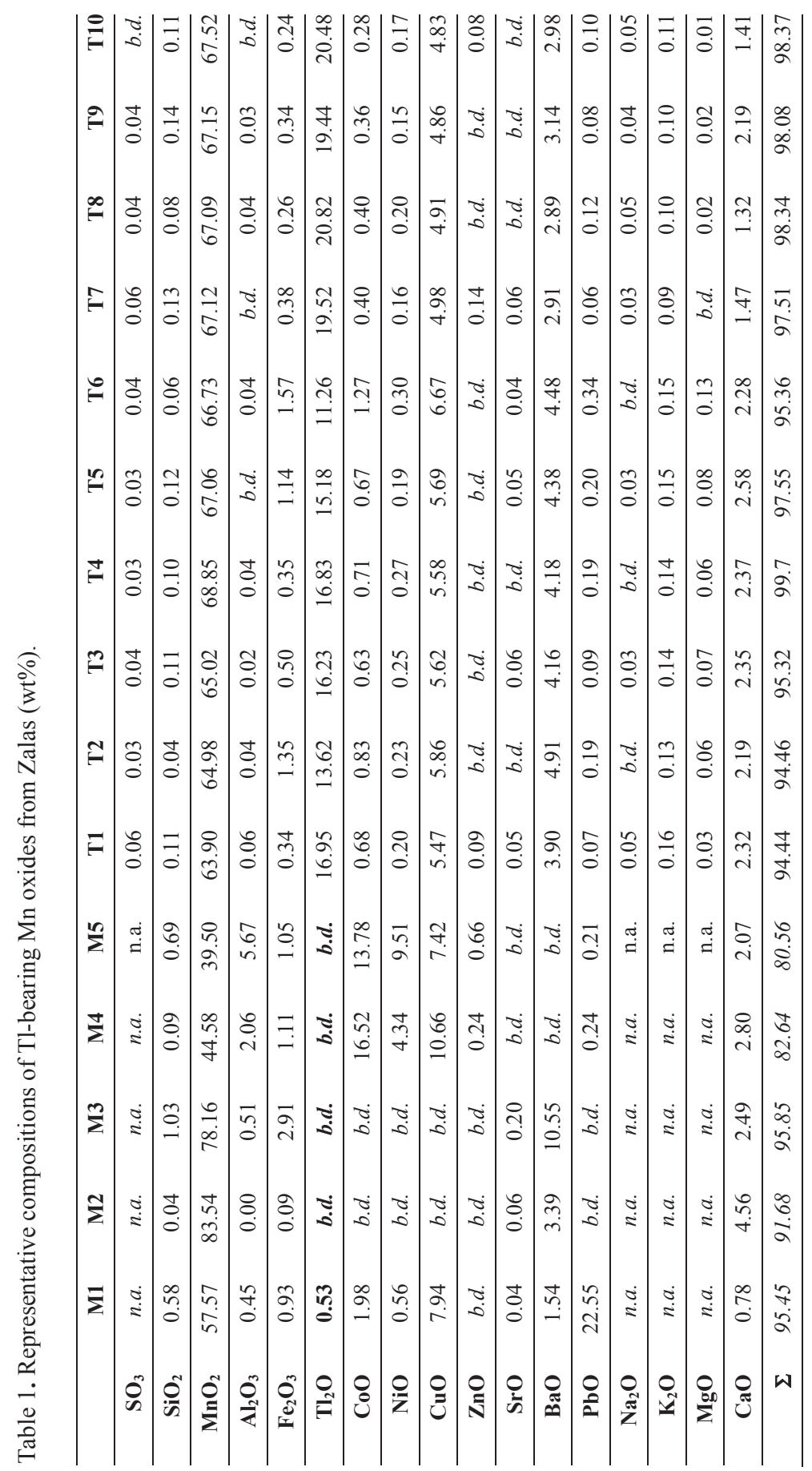




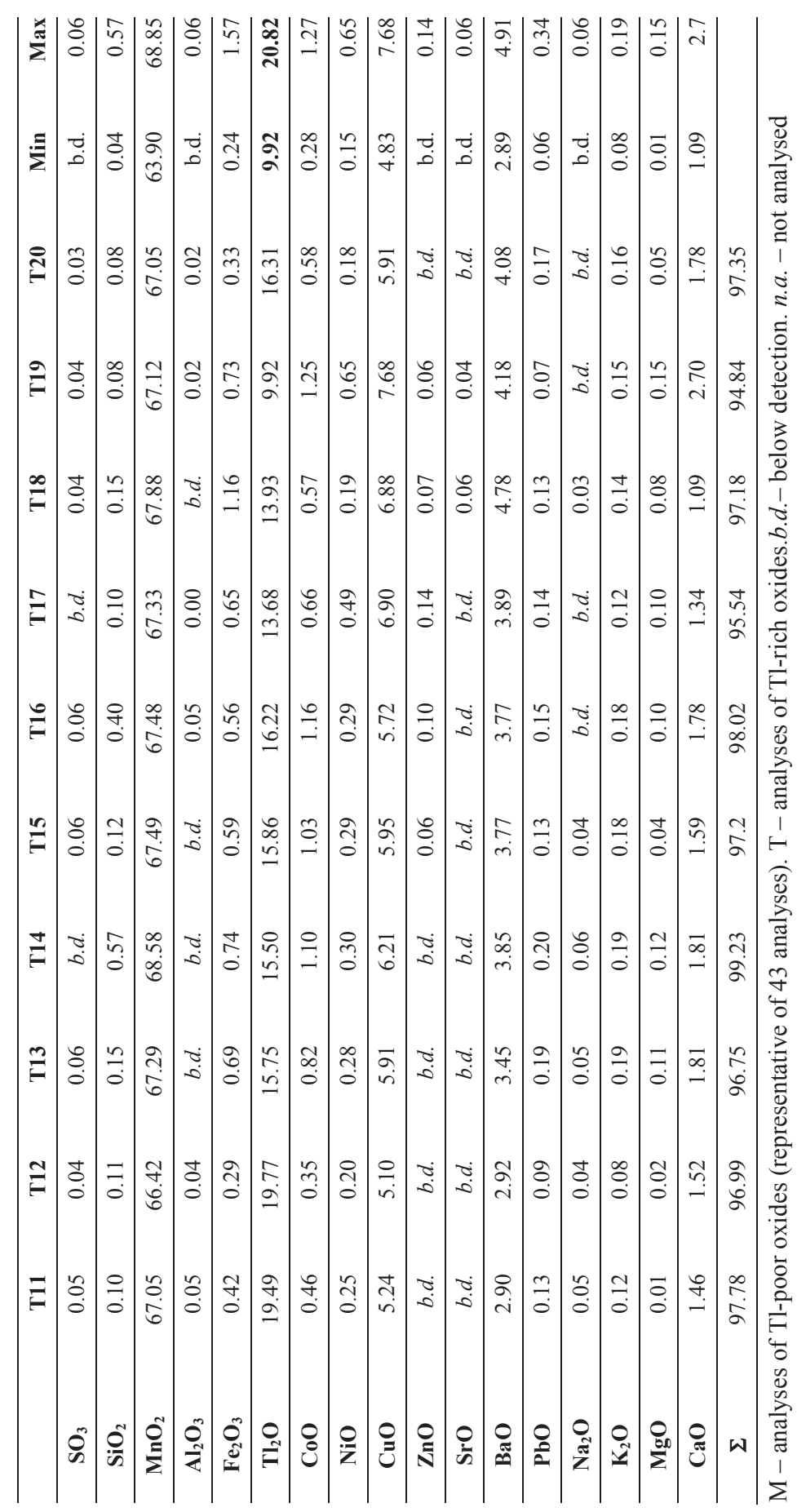




\section{Discussion}

$\mathrm{Tl}^{+}$and $\mathrm{Tl}^{3+}$ cations in the weathering zone are relatively quickly fixed by Mn oxides and organic matter (Kabata-Pendias 2011). Adsorption of Tl on a Mn-oxide matrix leads to a $\mathrm{Tl}$ concentration usually of the order of $100 \mathrm{ppm}$ in authigenic Mn precipitates (Peacock, Moon 2012) although, in some Pacific $\mathrm{MnO}_{2}$ nodules and crusts, higher Tl contents up to 675 ppm, have been recorded (Haynes et al. 1985; Koschinsky, Hein 2003; Hein et al. 2012). Data for Tl contents in individual Mn oxides are scarce. Critteden et al. (1962) noted up to $0.37 \mathrm{wt} \% \mathrm{Tl}$ in hollandite-cryptomelane from the Apache Mine in Arizona and, to our knowledge, this is probably the highest $\mathrm{Tl}$ content found in any Mn oxide to date. Similar, or even slightly higher, level of enrichment in $\mathrm{Tl}$ in the $\mathrm{MnO}_{2}$ oxides from Zalas is attained in the $\mathrm{Pb}$-bearing variety. Other examples of Tl-bearing $\mathrm{Mn}$ oxides include cryptomelane from natural black pigments (up to $0.23 \mathrm{wt} \%$; Jezequel et al. 2011), pyrolusite from New Ross in Canada (up to 0.15wt\%; Hewett 1968), and psilomelane from Central Kazakhstan (up to $0.1 \mathrm{wt} \%$; Voskresenskaya, Soboleva 1961).

In the CSM region, surface indications of polymetallic mineralization are known only from Karniowice (Fig. 1), where Co- and Ni-sulphides are disseminated within Permian travertine (Czerny 1992). Muszyński (1991) reported millerite, bravoite and cobaltite in ore veins cutting the CSM basement, and Górecka (1993) noted the presence of Tl in the Paleozoic-basement mineralization and in overlying Mesozoic rocks. Polymetallic ores containing sulphides, e.g. chalcopyrite, molybdenite, Bi minerals, scheelite, and carrying traces of $\mathrm{Ag}, \mathrm{Au}, \mathrm{Se}, \mathrm{Te}, \mathrm{Re}, \mathrm{Co}$ and $\mathrm{Ni}$, are typical of the basement, where they have been recognized in boreholes (e.g. Harańczyk 1978; Górecka, Nowakowski 1979; Oszczepalski et al. 2010; Mikulski et al. 2012). In the Upper Silesia region about 10-50 km from Zalas (Fig. 1), large $\mathrm{Zn}-\mathrm{Pb}$ deposits in Triassic dolomite have been exploited for a few centuries. The main sulphides in these deposits, galena and sphalerite are accompanied by pyrite and marcasite and are commonly enriched in Ag, Cd and Tl (Sawłowicz 1981). Metallurgical processing of the ores resulted in high $\mathrm{Tl}$ pollution of soils and waters in the area (e.g. Lis et al. 2003; Gruszecka, Wdowin, 2013; Vaněket al. 2013). Mayer and Sass-Gustkiewicz (1998) and Sutley et al. (1999) noted up to $0.5 \mathrm{wt} \% \mathrm{Tl}$, and Sawłowicz (1981) up to $1.5 \mathrm{wt} \%$ in Fe sulphides in the area. Harańczyk (1965) reported the highest $\mathrm{Tl}$ content in galena $(\sim 0.2 \mathrm{wt} \%)$ and up to $0.4 \mathrm{wt} \%$ in sphalerite. Bojakowska and Paulo (2013) documented $\mathrm{Tl}$ concentrations, up to $547 \mathrm{ppm}$, in the $\mathrm{Zn}-\mathrm{Pb}$ ores from the Trzebionka and Pomorzany mines. Kucha and Viaene (1993) found almost 2.3wt\% Tl in Fe oxysulfphides and Rajchel (2008) similar concentrations in melnikovite. Comparable $\mathrm{Tl}$ contents were found in the coexisting jordanite (1.56wt\%; Harańczyk 1958), and in jarosites (up to $2 \mathrm{wt} \%$ ) and $\mathrm{Mn}$ oxides of the Silesia-Krakow region $(<0.1 \mathrm{wt} \%$, Harańczyk 1965; Sutley et al. 1999). These numerous data corroborate the opinion that $\mathrm{Tl}$ is, at least, a trace element in the Paleozoic mineralization in the basement of CSM and a common and indicative component of the Triassic mineralization in the Krakow-Silesia region.

The occurrence of Tl-bearing $\mathrm{Mn}$ oxides at Zalas in close proximity to polymetallic encrustations suggests that $\mathrm{Tl}$ from a source in the CSM basement was, in a late stage of the ore mineralization there, transported along rejuvenated fault zones cutting the basement, deposited, and subsequently intensively weathered in an arid climate with participation of 
saline fluids. The fluids can be identified with brines and pore waters from the Carpathian flysch or from sediments of the Carpathian foredeep that were generated by compaction during the Sava phase of folding and nappe formation, and forced to the surface along faults and fractures in late Oligocene/early Miocene times (Gołębiowska et al. 2010). Passing up through the mineralization, they leached and transported away metallic components, mainly in the form of sulphate and halide complexes. The fluid chemistry is documented well by the presence of relics of the primary sulphides undergoing oxidation, trace secondary $\mathrm{Cu}$ sulphates, $\mathrm{Bi}$ oxychlorides and iodargyrite as the oxidation products, and rare small halite and sylvite cubes. All indicate a high degree of evaporation and salination during the oxidation of the primary ores, and, by the presence of malachite and iodargyrite in the supergene assemblage, an increased $\mathrm{pH}$ reaching 8-10 (Gołębiowska et al. 2010). Thus, the weathering of the primary ores and the formation of secondary compounds can be related to arid periods with a deep-seated water table, and to the evaporation of salt lakes or an inland sea that delivered halide and sulphate ions to the groundwater oxidation system in the Early-Middle Miocene.

The mobilization of Mn admixtures during oxidation of primary sulphides, e.g. from chalcopyrite, sphalerite, etc. and the hydrolysis and oxidation $\mathrm{Mn}^{2+}$ into $\mathrm{Mn}^{4+}$ can lead to the formation of $\mathrm{MnO}_{2}$ gels. The negative surface charge on $\mathrm{MnO}_{2}$ gels could have been responsible for the adsorption of numerous cations, including $\mathrm{Ca}^{2+}, \mathrm{Ba}^{2+}, \mathrm{Co}^{2+}, \mathrm{Ni}^{2+}, \mathrm{Cu}^{2+}$, $\mathrm{Pb}^{2+}, \mathrm{Tl}^{+}$and/or $\mathrm{Tl}^{3+}$, which had been leached from the primary ores encrusting fault breccia in the sandy limestone. Solubility constants of some metal hydroxides of interest are: $\mathrm{Ba}(\mathrm{OH})_{2} \cdot 8 \mathrm{H}_{2} \mathrm{O}=5 \cdot 10^{-3}, \mathrm{Ca}(\mathrm{OH})_{2}=5.5 \cdot 10^{-6}, \mathrm{Mn}(\mathrm{OH})_{2}=1.9 \cdot 10^{-13}, \mathrm{~Pb}(\mathrm{OH})_{2}=1.2 \cdot 10^{-15}$, $\mathrm{Ni}(\mathrm{OH})_{2}=2 \cdot 10^{-15}, \mathrm{Co}(\mathrm{OH})_{2}=1.6 \cdot 10^{-16}, \mathrm{Zn}(\mathrm{OH})_{2}=1.2 \cdot 10^{-17}, \mathrm{Cu}(\mathrm{OH})_{2}=2.2 \cdot 10^{-20}, \mathrm{Tl}(\mathrm{OH})_{3}$ $=6.3 \cdot 10^{-46}$. In addition, T1OH is highly soluble with $350 \mathrm{~g} / \mathrm{dcm}^{3}$ solubility (Lide 1996; Lin, Nriagu 1999). Furthermore, Mn oxides have a very high sorption capacity towards many trace elements, particularly metals, e.g., $\mathrm{Zn}, \mathrm{Ni}, \mathrm{Tl}, \mathrm{Pb}, \mathrm{V}, \mathrm{Cr}$, etc. (Manceau et al. 2002, 2007, 2014; Rehkämper et al. 2004; Grangeon et al. 2008, 2012; Peacock 2009; Peacock, Moon 2012; Voegelin et al. 2015). Generally, the metal cations are adsorbed onto Mn oxides in the order: $\mathrm{Na}^{+} \approx \mathrm{K}^{+}<\mathrm{Mg}^{2+}<\mathrm{Ca}^{2+}<\mathrm{Sr}^{2+}<\mathrm{Ba}^{2+}<\mathrm{Ni}^{2+}<\mathrm{Zn}^{2+}<\mathrm{Co}^{2+}<\mathrm{Mn}^{2+}<$ $\mathrm{Cu}^{2+}<\mathrm{Pb}^{2+}$ (Murray, 1975). Some species, including $\mathrm{Co}^{2+}, \mathrm{Mn}^{2+}$ and $\mathrm{Tl}^{+}$can be additionally oxidized by a layered birnessite-type oxide to 3-valent species with the simultaneous reduction of $\mathrm{Mn}^{4+/ 3+}$ to $\mathrm{Mn}^{3+/ 2+}$ (e.g. Manceau et al. 2007; Kämpf et al. 2000; Grangeon et al. 2008). Considering the probable diversified accessibility of these cations in the Zalas oxidation zone, it seems that the chemistry of Mn oxides from Zalas can be simply explained on the basis of the above mentioned features.

In the $\mathrm{Mn}$ oxides, high contents of $\mathrm{Cu}, \mathrm{Co}$ and $\mathrm{Ni}, \mathrm{Pb}$ and $\mathrm{Tl}$ suggest a direct link with the chemistry of the primary ore assemblage. Furthermore, many of the oxides, e.g. $\mathrm{Co}(\mathrm{Ni})$ $\mathrm{MnO}_{2}, \mathrm{Cu}-\mathrm{MnO}_{2}$ and $\mathrm{Pb}-\mathrm{MnO}_{2}$, occurring along with relics of the primary and supergene ores in the zone of polymetallic encrustations in the fault breccia are compositionally homogeneous; hydrolysis of mobile $\mathrm{Co}-\mathrm{Ni}, \mathrm{Cu}, \mathrm{Pb}$ and $\mathrm{Tl}$ compounds along with oxidation of soluble $\mathrm{Mn}^{2+}$, or quick absorption by $\mathrm{MnO}_{2}$ gels, is suggested. In contrast, $\mathrm{Ca}$ - and Ba$\mathrm{MnO}_{2}$ oxides generally lack polymetallic components derived from the primary ores and show fine zoning formed due the later adsorption of $\mathrm{Ca}^{2+}$ and $\mathrm{Ba}^{2+}$ on the surface of $\mathrm{MnO}_{2}$ gel as a result of higher $\mathrm{Ca}(\mathrm{OH})_{2}$ and $\mathrm{Ba}(\mathrm{OH})_{2}$ solubilities and less prone to adsorption. At 
Zalas, $\mathrm{Tl}$ concentrations reaching $20 \mathrm{wt} \%$ of the whole Mn oxide mass of $\mathrm{Tl}-\mathrm{MnO}_{2}$ type, were found in the marginal zone of the encrustations. As $\mathrm{Tl}(\mathrm{OH})$ has relatively high solubility, and thus unlikely to be quickly precipitated, it could migrate to areas more distant from the primary ore encrustations and other supergene components. The lack of $\mathrm{Tl}$ in the $(\mathrm{Co}, \mathrm{Ni})$ - and $\mathrm{Cu}$-bearing $\mathrm{MnO}_{2}$ oxides indicates that $\mathrm{Tl}$ could not be transported as the $\mathrm{Tl}^{3+}$ species as $\mathrm{Tl}(\mathrm{OH})_{3}$ is one of the least soluble metal hydroxides, and likely to precipitate close to the primary and supergene mineralization. Both observations are strong evidence that $\mathrm{Tl}^{+}$was the only mobile $\mathrm{Tl}$ species transported in the oxidation zone of the Zalas ore encrustations.

The $\mathrm{pH}-\mathrm{Eh}$ diagram for the Tl-O-H-S system (Brookins 1988) suggests that under oxidizing conditions, $\mathrm{Tl}_{2} \mathrm{O}, \mathrm{Tl}_{2} \mathrm{O}_{3}$ and $\mathrm{Tl}_{2} \mathrm{O}_{4}$ oxides dominate in the Eh-pH space in order of increasing Eh, and $\mathrm{Tl}^{+}$dominates under relatively low oxidizing conditions. $\mathrm{Tl}^{3+}$ can appear only in extremely acidic $(\mathrm{pH}<2)$ and highly oxidizing $(\mathrm{Eh}>\sim 0.7 \mathrm{~V})$ solutions, a situation inapplicable to the Zalas supergene zone, as shown by the coexistence of iodargyrite with malachite and cuprite (see Fig. 4 in Gołębiowska et al. 2010). Perhaps, it could be oxidized into $\mathrm{Tl}^{3+}$ when adsorbed onto $\mathrm{MnO}_{2}$ gel, but the extent of the oxidation would be $\mathrm{pH}$ dependant (e.g. Wan et al. 2014). Although some photochemically-catalyzed reactions and/or microbiological processes may also lead to $\mathrm{Tl}^{+}$-into- $\mathrm{Tl}^{3+}$ oxidation (Twining et al. 2003; Karlsson et al. 2006), these processes require at least partial exposure of rock, and they also could not have applied to the oxidation of the polymetallic encrustations at Zalas.

Acknowledgements. The work was financially supported by AGH University of Science and Technology grant no 11.11.140.319. We are grateful to anonymous reviewers for their constructive comments and to A. Włodek (AGH University of Science and Technology) and P. Dzierżanowski (University of Warsaw) for their help with the manuscript.

\section{References}

Balić-Žunić, T., Moëlo, Y., Lončar, Ž., \& Micheelsen, H. (1994). Dorrallcharite, $\mathrm{Tl}_{0,8} \mathrm{~K}_{0,2} \mathrm{Fe}_{3}(\mathrm{SO})_{2}(\mathrm{OH})_{6}$, a new mineral of the jarosite-alunite family. European Journal of Mineralogy, 6, 255-264. DOI: $10.1127 /$ ejm $/ 6 / 2 / 0255$.

Bodeï, S., Manceau, A., Geoffroy, N., Baronnet, A., \& Buatier, M. (2007). Formation of todorokite from vernadite in Ni-rich hemipelagic sediments. Geochimica et Cosmochimica Acta, 71, 5698-5716. DOI:10.1016/j.gca.2007.07.020.

Bojakowska, I., \& Paulo, A. (2013). Thallium in mineral resources extracted in Poland. Proceedings of the $16^{\text {th }}$ International Conference on Heavy Metals in the Environment, 23-27 September 2012, Rome, Italy. E3S Web of Conferences, 1, 14006. DOI: 10.1051/e3sconf/20130114006.

Brookins, D.G. (1988). Eh-pH Diagrams for Geochemistry. Springer-Verlag Berlin.

Buła, Z. (2002). Geological atlas of the Palaeozoic without the Permian in the border zone of the Upper Silesian and Małopolska Blocks. Explanatory text. Państwowy Instytut Geologiczny. Warszawa.

Critteden, M.S., Cuttitta, F., Rose, H.D., \& Fleischer, M. (1962). Studies on manganese oxide minerals VI. Thallium in some manganese oxides. American Mineralogist, 47, 1461-1467.

Czerny, J. (1992). Hydrothermal mineralization phenomena in Karniowice Travertine near Cracow. Mineralogia Polonica, 23, 3-13.

Daiyan, Ch., Guanxin, W., Zhenxi, Z., \& Yuming, Ch. (2003). Lanmuchangite, a new thallium (hydrous) sulphate from Lanmuchang, Guizhou Province, China. Chinese Journal of Geochemistry, 22(2), 185-192. 
Gołębiowska, B., Pieczka, A., Rzepa, G., Matyszkiewicz, J., \& Krajewski, M. (2010). Iodargyrite from Zalas (Cracow area, Poland) as an indicator of Oligocene-Miocene aridity in Central Europe. Palaeogeography, Palaeoclimatology, Palaeoecology, 296, 130-137. DOI:10.1016/j.palaeo.2010.06.022

Gołębiowska, B., Rzepa, G., \& Kraczkowska, I. (2007). Fe-Mn on the Middle-Upper Jurassic boundary in Zalas near Cracow (S Poland). Mineralia Slovakia, Geovestnik, 2, 8.

Górecka, E. (1993). Genetic model of $\mathrm{Zn}-\mathrm{Pb}$ deposit in the Olkusz ore district (S Poland). Archiwum Mineralogiczne, 49, 23-80.

Górecka, E., \& Nowakowski, A. (1979). Ore deposits associated with acid intrusives and related rocks in the Zawiercie region. Prace Instytutu Geologicznego, 95, 97-108.

Gradziński, R., Gradziński, M., \& Michalik, S. (1994). Natura i kultura w krajobrazie Jury. Przyroda. Kraków: Wyd. Zarząd Zespołu Jurajskich Parków Krajobrazowych w Krakowie.

Grangeon, S., Lanson, B., Lanson, M., \& Manceau, A. (2008). Crystal structure of Ni-sorbed synthetic vernadite: A powder X-ray diffraction study. Mineralogical Magazine, 72, 1197-1209. DOI: 10.1180/minmag.2008.072.6.1279.

Grangeon, S., Manceau, A., Guilhermet, J., Gaillot, A.-C., Lanson, M., \& Lanson, B. (2012). Zn sorption modifies dynamically the layer and interlayer structure of vernadite. Geochimica et Cosmochimica Acta, 85, 302-313. DOI:10.1016/j.gca.2012.02.019.

Gruszecka, A.M., \& Wdowin, M. (2013). Characteristics and distribution of analyzed metals in soil profiles in the vicinity of postflotation waste site in the Bukowno region, Poland. Environmental Monitoring and Assessment, 185, 8157-8168. DOI 10.1007/s10661-013-3164-9.

Harańczyk, C. (1958). Thallium jordanite. Bulletin de l'Academie Polonaise des Sciences, Serie des sciences chimiques, geologiques et geographiques, 6, 201-208.

Harańczyk, C. (1965). Geochemistry of the ore minerals from Silesia-Cracow zinc and lead deposits. Prace Geologiczne, 30, 5-111. [in Polish with English summary].

Harańczyk, C. (1978). Kraków Paleozoic telluric province (in Polish with English summary). Przegląd Geologiczny, 26, 337-343 [In Polish with English summary].

Haynes, B.W., Law, S.S., Barron, D.C., Kramer, G.W., Maeda, R., \& Magyar, M.J. (1985). Pacific manganese nodules: characterization and processing. Bulletin of the United States Department of the Interior, Bureau of Mines, 679.

Hein, J.R., Conrad, T.A., Frank, M., Christl, M., \& Sager, W.W. (2012). Copper-nickel-rich, amalgamated ferromanganese crust-nodule deposits from Shatsky Rise, NW Pacific. Geochemistry, Geophysics, Geosystems, 13(10), 1-23. DOI: 10.1029/2012GC004286

Hewett, D.F. (1968). Silver in veins of hypogene manganese oxides. Geological Survey Circular, 553, United States Department of the Interior. Washington.

Jezequel, P., Wille, G., Bény, C., Delorme, F., Jean-Prost, V., Cottier, R., Breton, J., Duré, F., \& Despriee, J. (2011). Characterization and origin of black and red Magdalenian pigments from Grottes de la Garenne (Valléemoyenne de la Creuse-France): a mineralogical and geochemical approach of the study of prehistorical paintings. Journal of Archaeological Science, 38(6), 1165-1172. DOI: 10.1016/j.jas.2010.12.014.

John Peter, A.L., \& Viraraghavan, T. (2005). Thallium: a review of public health and environmental concerns. Environment International, 31(1), 493-501. DOI: 10.1016/j.envint.2004.09.003.

Jović, V. (1993). Thallium in rocks, soils and plants: past progress and future needs. Neues Jahrbuch für Mineralogie, Abhandlungen, 166, 43-52.

Kabata-Pendias, A. (2011). Trace elements in soils and plants $\left(4^{\text {th }}\right.$ ed.). Boca Raton: CRC Press.

Kämpf, N., Scheinost A.C., \& Schultze, D.G. (2000). Oxide minerals. In: Sumner ME (ed.) Handbook of soil science, CRC Press.

Karlsson, U., Karlsson, S., \& Duker, A. (2006). The effect of light and iron(II)/iron(III) on the distribution of $\mathrm{Tl}(\mathrm{I}) / \mathrm{Tl}(\mathrm{III})$ in fresh water systems. Journal of Environmental Monitoring, 8(6), 634-640. DOI: 10.1039/B516445A.

Karpova, K.N., Kon'kova, E.A., Larkin, E.D., \& Savel'ev, V.F. (1958). Avicennite, a new mineral (in Russian). Doklady Akademii Nauk Uzbekistan SSR, 2, 23-26.

Koschinsky, A., \& Hein, J.R. (2003). Uptake of elements from seawater by ferromanganese crusts: solid phase associations and seawater speciation. Marine Geology, 198, 331-351. DOI: 10.1016/S0025-3227(03)00122-1.

Kucha, H., \& Viaene, W. (1993). Compounds with mixed and intermediate sulfur valences as precursors of banded sulfides in carbonate-hosted $\mathrm{Zn}-\mathrm{Pb}$ deposits in Belgium and Poland. Mineralium Deposita, 28, 13-21.

Lide, D., R. (1996). Handbook of chemistry and physics, $77^{\text {th. }}$ ed. 
Lin, T.S., \& Nriagu, J. (1999). Thallium speciation in the Great Lakes. Environmental Science and Technology, 33(19), 3394-3397. DOI: 10.1021/es981096o.

Lis, J., Pasieczna, A., Karbowska, B., Zembrzuski, W., \& Lukaszewski, Z. (2003). Thallium in soils and stream sediments of a Zn-Pb mining and smelting area. Environmental Science and Technology, 37(20), 4569-4572. DOI: $10.1021 / \mathrm{es} 0346936$.

Manceau, A., Kersten, M., Marcus, M.A., Geoffroy, N., \& Granina, L. (2007). Ba and Ni speciation in a nodule of binary Mn oxide phase composition from Lake Baikal. Geochimica et Cosmochimica Acta, 71(8), 1967-1981. DOI:10.1016/j.gca.2007.02.007.

Manceau, A., Lanson, B., \& Drits, V.A. (2002). Structure of heavy metal sorbed birnessite. Part III: Results from powder and polarized extended X-ray absorption fine structure spectroscopy. Geochimica et Cosmochimica Acta, 66(15), 2639-2663. DOI:10.1016/S0016-7037(02)00869-4.

Manceau, A., Lanson, M., \& Takahashi, Y. (2014). Mineralogy and crystal chemistry of Mn, Fe, Co, Ni, and Cu in a deep-sea Pacific polymetallic nodule. American Mineralogist, 99(10), 2068-2083. DOI: 10.2138/am-20144742 .

Marciniak, H., Diduszko, R., \& Kozak, M. (2006). XRAYAN. Program do rentgenowskiej analizy fazowej, wersja 4.0.1. Koma, Warszawa.

Matyszkiewicz, J. (1997). Microfacies, sedimentation and some aspects of diagenesis of Upper Jurassic sediments from the elevated part of the Northern peri-Tethyan Shelf: a comparative study on the Lochen area (Schwäbische Alb) and the Cracow area (Cracow-Wieluń Upland, Polen). Berliner Geowissenschaftliche Abhandlungen, 21. Berlin: Selbstverlag Fachbereich Geowissenschaften, 1-111.

Matyszkiewicz, J., Krajewski, M., \& Żaba, J. (2006). Structural control on the distribution of Upper Jurassic carbonate buildups in the Kraków-Wieluń Upland (South Poland). Neues Jahrbuch für Geologie und Paläontologie, Monatshefte, 3,182-192.

Mayer, W., \& Sass-Gustkiewicz, M. (1998). Geochemical characterization of sulphide minerals from the Olkusz lead-zinc ore cluster, Upper Silesia (Poland), based on laser ablation data. Mineralogia Polonica, 29, 87-105.

Mikulski, S.Z., Oszczepalski, S., \& Markowiak, M. (2012). The occurrence and prospective resources of molybdenum and tungsten ores in Poland. Biuletyn Państwowego Instytutu Geologicznego, 448, 297-314. [In Polish with English summary].

Murray, W. (1975). The interactions of metal ions at the manganese dioxide-solution interface. Geochimica et Cosmochiica Acta 39, 505-51.

Muszyński, M. (1991). Mineral veins in rocks of the sub-Devonian basement of the Cracow-Silesian Monocline. Zeszyty Naukowe AGH, 52, 7-129. [In Polish with English summary].

Nawrocki, J., Polechońska, O., Lewandowska, A., \& Werner, T. (2005). On the palaeomagnetic age of the Zalas laccolith (southern Poland). Acta Geologica Polonica, 55, 229-236.

Oszczepalski, S., Markowiak, M., Mikulski, S.Z., Lasoń, K., Buła, Z., \& Habryn, R. (2010). Porphyry Mo-Cu-W mineralization within Precambrian-Paleozoic rocks - prospectivity analysis of the border zone of the Upper Silesia and Małopolska Block. Biuletyn Państwowego Instytutu Geologicznego, 439, 339-354. [In Polish with English summary].

Peacock, C.L. (2009). Physicochemical controls on the crystal-chemistry of Ni in birnessite: Genetic implications for ferromanganese precipitates. Geochimica et Cosmochimica Acta, 73(12), 3568-3578. DOI: 10.1016/j.gca.2009.03.020.

Peacock, C.L., \& Moon, E.M. (2012). Oxidative scavenging of thallium by birnessite: explanation for thallium enrichment and stable isotope fractionation in marine ferromanganese precipitates. Geochimica et Cosmochimica Acta, 84, 297-313. DOI: 10.1016/j.gca.2012.01.036.

Rajchel, B. (2008). Geochemia Tl, As, Cd, Pb w rudach oraz odpadach hutniczych Zn-Pb Górnego Śląska. Unpublished Ph.D. thesis. AGH University of Science and Technology, Kraków. [In Polish].

Rehkämper, M., Frank, M., Hein, J.R., \& Halliday, A. (2004). Cenozoic marine geochemistry of thallium deduced from isotopic studies of ferromanganese crusts and pelagic sediments. Earth and Planetary Science Letters, 219, 77-91. DOI: 10.1016/S0012-821X(03)00703-9.

Sawłowicz, Z. (1981). Forma występowania domieszek Pb, As, Tl i Zn w pirycie ze złóż śląsko-krakowskich . Rudy i Metale Nieżelazne, 26, 355-362. [In Polish]

Schmiermund, R. (2008). Thallium - a potential environmental and occupational "driver" for mining? E2Geochemistry, Inc. Newsletter, Economic \& Environmental Geochemistry, Inc. (E2Geochemistry.com), 1, $1-10$. 
Sutley, S., Sass-Gustkiewicz, M., Mayer, W., \& Leach, D. (1999). Mineralogy and chemistry of oxidized ores from the Upper Silesia Mississippi Valley-type zinc-lead deposits, Poland. USGS Open-File Report, 99-394, $1-44$.

Twining, B., Twiss, M., \& Fisher, N.S, (2003). Oxidation of thallium by freshwater plankton communities. Environmental Science and Technology, 37(12), 2720-2726. DOI: 10.1021/es026145i.

Vaněk, A., Chrastný, V., Komárek, M., Penížek, V., Teper, L., Cabala, J., \& Drábek, O. (2013). Geochemical position of thallium in soils from a smelter-impacted area. Journal of Geochemical Exploration, 124, 176-182. DOI:10.1016/j.gexplo.2012.09.002.

Voegelin, A, Pfenninger, N., Petrikis, J., Majzlan, J., Plötze, M., Senn, A.C., Mangold, S., Steininger, R., \& Göttlicher, J. (2015). Thallium Speciation and Extractability in a Thallium- and Arsenic- Rich Soil Developed from Mineralized Carbonate Rock. Environmental Science and Technology, 49(9), 5390-5398. DOI: 10.1021/acs.est.5b00629.

Voskresenskaya, N.T., \& Soboleva, L.T. (1961). Once more on thallium in manganese minerals. Geokhimiya, 3, 276-278. [In Russian with English summary].

Wan, S.L., Ma, M.H., Lv, L., Qian, L.P., Xu, S.Y., Xue, Y., Ma, Z.Z (2014). Selective capture of thallium(I) ion from aqueous solutions by amorphous hydrous manganese dioxide. Chemical Engineering Journal, 239, 200206. DOI:10.1016/j.cej.2013.11.010.

Wedepohl, K.K. (1978). Handbook of Geochemistry, 2(5), Berlin, Heidelberg, New York: Springer-Verlag.

Zhou, T.F., Fan, Y., Yuan, F., Wu, M.A., Hou, M.J., Voicu, G., Hu, Q.H., Zhang, Q.M., \&Yue, S.C. (2005). A preliminary geological and geochemical study of the Xiangquan thallium deposit, eastern China: the world's first thallium-only mine. Mineralogy and Petrology, 85, 243-251. DOI 10.1007/s00710-005-0088-2.

Żaba, J. (1999). The structural evolution of Lower Palaeozoic succession in the Upper Silesia Block and Małopolska Block border zone, southern Poland . Prace Państwowego Instytutu Geologicznego, 166, 1-162. [In Polish with English summary]. 